Geografia e Ordenamento do Território, Revista Electrónica

Centro de Estudos de Geografia e Ordenamento do Território

http://cegot.org

ISSN :2182-1267

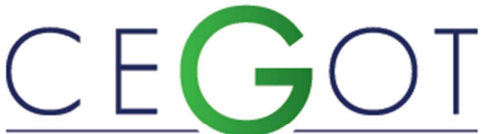

Centro de Estudos de Geografia e Ordenamento do Território
SANTOS, CLÓVIS DO

Universidade Estadual de Feira de Santana - UEFS / Departamento de Ciências Humanas e Filosofia. Feira de Santana, Bahia, Brasil

Rua Ismar Prates, Lote 63, casa 06. Cond. Porto dos Coqueiros. Bairro de Buraquinho. Lauro de Freitas - Bahia. CEP: 42.700-000, Brasil

cloviscaribe@uol.com.br

\title{
O espírito do capitalismo na ocupação dos cerrados brasileiros nos estados da Bahia e do Piauí
}

The spirit of capitalism in the occupation of Brazilian cerrados in state of Bahia and Piauí

Referência: Santos, Clóvis do (2015). O espírito do capitalismo na ocupação dos cerrados brasileiros nos estados da Bahia e do Piauí. Revista de Geografia e Ordenamento do Território (GOT), n.o 8 (dezembro). Centro de Estudos de Geografia e Ordenamento do Território, p.229-253, dx.doi.org/10.17127/got/2015.8.012

\section{RESUMO}

Esse artigo analisa as transformações econômicas, sociais e políticas ocorridas nos Cerrados dos Estados da Bahia e do Piauí, a partir do final da década de 1970, com o recente processo de ocupação dos seus territórios, na implantação de uma moderna agricultura com a produção de grãos no Brasil. Processo de pujante expansão da fronteira agrícola que incorporou áreas localizadas nos dois Estados e está inserido em uma perspectiva global, de fluxos traçados pelas principais corporações multinacionais (tradings) vinculadas ao agronegócio. Discute-se regularidades, mostra deslocamentos e transformações, assim como tenta explicitar as determinações mais gerais que regeram os dois fenômenos, partindo do conjunto de ideias de Max Weber, apresentando uma compreensão e interpretação do que ocorreu nos dois territórios como uma ação social.

Palavras-chave: Espaço; Cerrados; Modernização; Agricultura; Fronteira Agrícola; Ação Social.

\section{ABSTRACT}

This article analyzes the economic, social and political changes happened in the Cerrado of the States of Bahia and Piaui, from the end of the 1970s, with the recent process of 
occupation of its territories in the implementation of modern agriculture with grains production in Brazil. This process causes vigorous expansion of the agricultural frontier that incorporated areas located in the two States, inserted in a global perspective of flows drawn by the major multinational corporations (trading) linked to agribusiness. It discusses regularities, shows up shifts and transformations, as well as attempts to explain the more general determinations which lead the two phenomena, starting from the set of Max Weber's ideas as well as having an understanding and interpretation of what happened in the two territories as an action social.

Keywords: Space; Cerrado; Modernization; Agriculture; Agricultural border; Social Action.

\section{Introdução}

Esse artigo trata das transformações econômicas, sociais e políticas ocorridas nos Cerrados $^{1}$ dos Estados da Bahia e do Piauí ${ }^{2}$, a partir do final da década de 1970, com o recente processo de ocupação dos seus territórios ${ }^{3}$ com a moderna agricultura produtivista de grãos. Trata, ainda que de forma sintética, sobre à formação socioespacial de um determinado espaço que faz parte de um território específico, que incorporou a moderna

\footnotetext{
${ }^{1}$ Cerrados: tipo bastante característico de cobertura vegetal que vai desde os campos limpos até uma vegetação bastante densa, com os rios das maiores bacias hidrográficas brasileiras: as do Amazonas, Tocantins, Paraná e São Francisco. Ocupando cerca de $25 \%$ do território nacional, com áreas que se estendem por mais de 204 milhões de hectares, dos quais 50 milhões apresentam potencial de uso para a agricultura. Sua vegetação e "sua imensa área contínua, foram sempre capazes de despertar o interesse e a cobiça dos estrangeiros, como um estigma que pesasse sobre a aparente monotonia de sua paisagem" (SAN MARTIN \& PELEGRINI, 1984, p.45). Possui traços peculiares, porém não se trata de um espaço homogêneo e nem uniforme, quanto à ocorrência e distribuição de seus recursos naturais. Ao contrário. Abrigam uma elevada e rica diversidade ambiental e uma imensa desigualdade social.

${ }^{2}$ Neste trabalho, o sentido de "Espírito" é puramente hegeliano. Na filosofia hegeliana, que se convencionou chamar de Filosofia do Real, que compreende a Natureza e o Espírito, este último, tradicionalmente, é tratado na Filosofia como um sujeito poderoso, que emerge acima do mundo material. Remetemo-nos a Hegel e ao uso de uma das categorias mais ricas da sua filosofia porque foi ele que inaugurou o discurso da modernidade, introduzindo o tema e estabelecendo regras que dariam validade ao seu discurso. Declarava com ênfase que toda filosofia não é outra coisa senão o pensamento do seu tempo, além de reconhecer a si mesma como esse pensamento do tempo (HABERMAS, 2000).

${ }^{3}$ Neste trabalho território é fundamentalmente um espaço definido e delimitado a partir de relações e do exercício de poder, quer se faça referência ao poder público, estatal, quer ao poder das grandes empresas que estendem os seus tentáculos por grandes áreas territoriais, ignorando as fronteiras políticas. "Usado indistintamente ao lado de região, de 'cidade', 'âmbito', 'dimensão', etc. Isso tudo muito embora se diga, ao mesmo tempo, que existem estreitas relações entre povos e territórios, que essas estreitas relações reforçam o sentido de pertinência cultural, que pré-existem a qualquer forma jurídico-institucional da sociedade" (SOLINís, p. 266, 2009). Quanto a compreensão sobre o conceito de espaço, entendemos que a que se adequa às premissas aqui incorporadas é a que nos apresentou o professor Milton Santos (1978), em que "o espaço deve ser considerado como um conjunto de relações realizadas através de funções e formas que se apresentam como testemunho de uma história escrita por processos do passado e do presente. ..... por relações sociais que estão acontecendo diante de nossos olhos e que se manifestam através de processos e funções....um verdadeiro campo de forças cuja a aceleração é desigual. Daí porque a evolução espacial não se faz de forma idêntica em todos os lugares" (p. 122).
} 
produção de grãos, principalmente soja, cuja expansão é limitada pela posição subordinada da produção local nos circuitos comerciais ou industriais e que "se caracterizaram por intensas transformações decorrentes de um fluxo de capitais que não são gerados pelas condições de produção anteriores na região, mas que é produto do desenvolvimento de necessidades econômicas e sociais geradas em outras regiões do país e do mundo" (SANTOS FILHO et al., 1988, p. 63-64). O que aqui se apresenta é a continuidade de uma pesquisa em que os seus resultados serão de grande importância para compreender, a partir das categorias de análise da sociologia e da geografia, o que possibilitou alguns grupos econômicos e sociais ligados ao agronegócio de origem nacional e internacional nos últimos 30 anos - e, mais precisamente nas duas últimas décadas, depois de ter ocupado a fronteira agrícola que era o Oeste da Bahia - viessem, beneficiada pelo valor relativamente baixo da terra, a ocupar uma nova fronteira agrícola delimitada com base nos espaços de cerrados existentes no território de quatro Estados fronteiriços: Maranhão, Tocantins, Piauí e Bahia: MATOPIBA ${ }^{4}$.

Pretendemos discutir regularidades, apresentar deslocamentos e transformações, identificando continuidades e descontinuidades, semelhanças e diferenças nos processos de ocupação no Brasil de cerrados fronteiriços dos Estados da Bahia e do Piauí (figura 1), assim como tentar explicitar as determinações mais gerais que regeram os dois fenômenos, compreendendo, captando o sentido das suas atividades. Pois, o que vem ocorrendo nesses espaços são processos desterritorializantes e reterritorializantes, com a instalação de uma nova divisão territorial do trabalho, cujas implicações econômicas e políticas têm sido pouco estudadas nos seus Estados de ocorrência, sobretudo seus pontos de convergência histórica.

Tem sido comum no meio acadêmico e nos aparelhos institucionais dos Estados de ocorrência dessas ações uma constatação do pouco conhecimento ou pouco interesse intelectual pelas reais consequências da nova territorialidade que se constitui a partir da nova dinâmica agrícola ocorrida nos seus espaços de cerrados que vem propiciando a

\footnotetext{
${ }^{4} \mathrm{O}$ nome MATOPIBA vem da junção das duas primeiras letras dos nomes dos Estados do Maranhão, Tocantins, Piauí e Bahia e das suas divisas territoriais. A nomenclatura ganhou relevância nos últimos dez anos. E devido ao fato de grupos econômicos e produtores modernos se instalarem nos cerrados desses Estados, passou a significar sinônimo de grandes investimentos públicos e privados, nacionais e internacionais no setor agrícola da economia nacional. Tanto assim que, no dia 06 de maio de 2015, a presidenta Dilma Rousseff assinou decreto criando a região do MATOPIBA. Com o decreto, foi delimitada a sua área, sua territorialidade e apresentado todos os seus potenciais. É uma das últimas regiões agrícolas do mundo em expansão, que cresce com o agronegócio e sofre com a falta de infraestrutura de energia e estrada. Trata-se de um território em que se observam profundas transformações da sua base técnica. A pecuária na região, em função do maior emprego de tecnologia, tem ocupado espaços cada vez menores, proporcionando a ampliação da área de produção de grãos (principalmente soja, milho e algodão).
} 
constituição de novas estruturas sociais, novas relações, outras identidades e formas de organização socioeconômica.

A moderna agricultura produtivista ${ }^{5}$ nos cerrados do país é uma realidade que se transformou, de forma mais acelerada, desde os meados da década de 1970 e início da década de 1980. Transformou-se para os aparelhos de Estado e os seus representantes em uma vaca sagrada ${ }^{6}$ da economia nacional e, por isso, sabemos que desvendar teoricamente o processo de ocupação dos cerrados brasileiros com a moderna agricultura não é uma tarefa intelectual simples. Até porque, desde a elaboração da Constituinte, em 1988, foi formada, no Congresso Nacional, uma bancada de parlamentares ruralistas vinculada aos agronegócios e extremamente aguerrida, corporativa e incrustradas nos aparelhos e nas estruturas de poder do Estado, com um largo apoio intelectual e financeiro das empresas internacionais vinculadas às commodities.

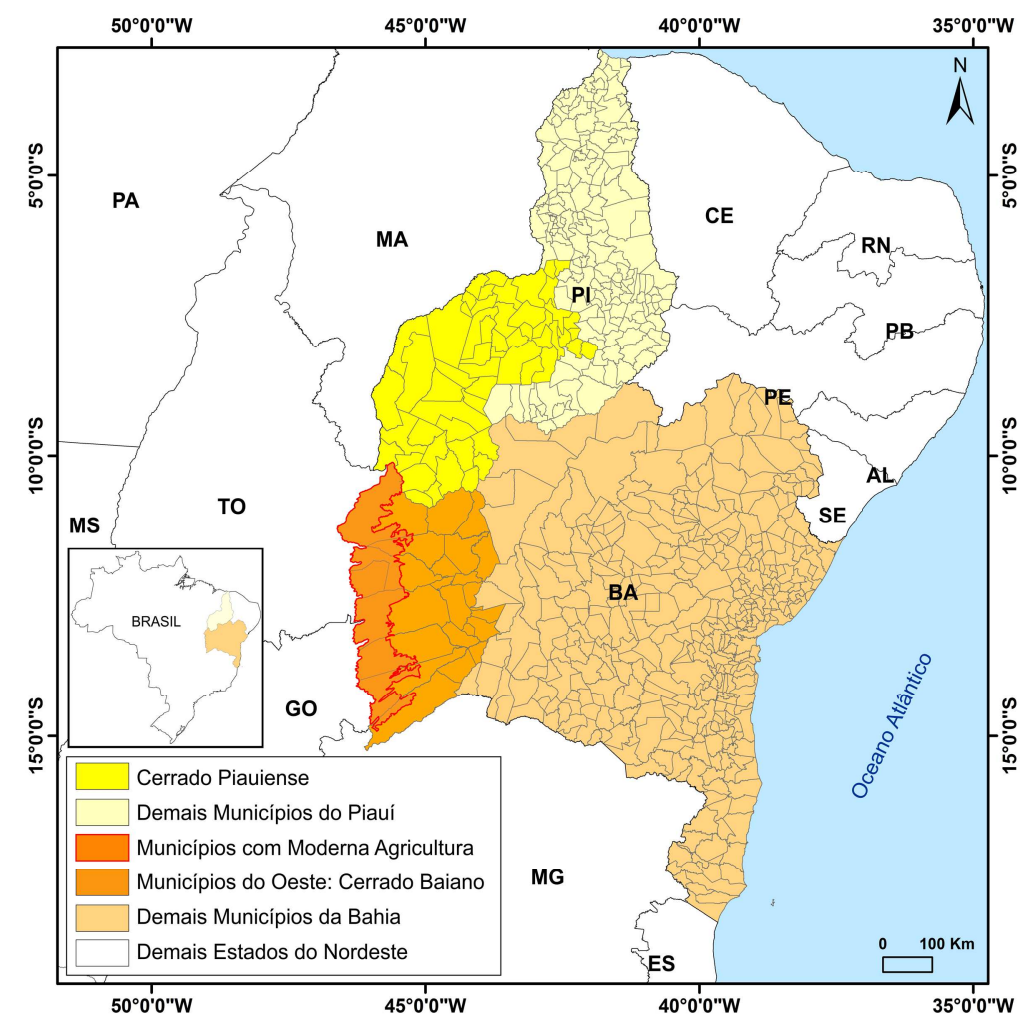

Figura 1 - Brasil: Estados da Bahia e Piauí, destaques para seus espaços de Cerrados. Fonte: IBGE

\footnotetext{
${ }^{5}$ As designações de moderna agricultura produtivista praticada nos cerrados brasileiro deve ser entendida nesse texto como uma forma de produzir com características diferentes aos presentes nos núcleos de produtores que são conceituados como parte da agricultura familiar ou dos grupos de produtores rurais conceituados como camponeses ou produtores tradicionais.

${ }^{6}$ Trata-se de uma analogia com o aspecto religioso em que na Índia, na maioria dos seus estados, o abate desse animal é proibido. A vaca pode circular com desenvoltura pelas ruas sem ser incomodada.
} 


\section{Método}

Partindo do conjunto de ideias de Max Weber, de autores e intérpretes do pensamento weberiano, buscamos apresentar uma compreensão e interpretação das transformações ocorridas nos dois territórios ${ }^{7}$ como uma ação social, dando alguma ênfase aos resultados da racionalidade que vem se apresentando durante a execução do processo de ocupação desses dois espaços de cerrados, que "mesmo incompleto na formação de uma mentalidade mais compatível com critérios modernos pode ser olhado com olhos positivos, como, por exemplo, a ausência de completa impessoalidade nas relações humanas, mesmo as comerciais" (WEGNER, 2000, p. 180).

Compreender, interpretar e comparar o fenômeno em uma perspectiva sociológica e geográfica, tendo como ponto de partida que os fatores naturais e técnicos não foram somente os principais responsáveis e encadeadores da atual dinâmica que os dois territórios vivem hoje. Também não consideramos ou concordarmos com as análises que o fator decisivo para o desencadeamento dessa nova dinâmica agrícola foi a "superioridade" da cultura econômica dos gaúchos e sulistas ${ }^{8}$, da qual originou majoritariamente a diáspora ou ainda o atual desencaixe das relações vitais e tradicionais que ocorriam historicamente nesses espaços.

Baseamo-nos nas concepções weberianas ${ }^{9}$ para esse estudo porque não se pode ignorar que, no tocante a domínios mais específicos das Ciências Sociais - tais como os estudos dos modelos de desenvolvimento presentes nas sociedades contemporâneas, dos processos de modernização, das relações entre cultura e construções de símbolos -, a influência de Weber é fundamental para as explanações que permitem descrever e interpretar os

\footnotetext{
${ }^{7}$ Parte do território de sete, dos vinte e três municípios, que contam com áreas de cerrados no Oeste baiano e em 23 (vinte e três) "eleitos" por meio de estudos realizados pelo Banco do Nordeste do Brasil, em 1998, para implementação de estratégias dinamizadoras de um complexo agroindustrial, integrado ao processo de expansão da produção da soja para as fronteiras agrícolas do Nordeste e Centro-Oeste, dos 55 (cinquenta e cinco municípios) que fazem parte da Macrorregião dos Cerrados Piauienses, conforme a Lei Complementar № 87, de 22 de agosto de 2007, aprovada pela Assembleia legislativa do Piauí.

${ }^{8} \mathrm{Em}$ uma referência aos novos produtores que se instalaram no Oeste da Bahia e no Sul do Piauí. Parte significativa desses imigrantes são originários do sul do país, dos Estados de Santa Catarina, Paraná e Rio Grande do Sul. Estados que apresentam dinâmica econômica e um certo índice de modernização do seu setor agrícola.

9A obra clássica de Weber "A Ética Protestante e o 'Espirito' do Capitalismo", lançado em 1904-5 e ampliado em 1920, onde o autor procura compreender um importante fenômeno que é o maior desenvolvimento capitalista que ocorre nos países de confissão protestante, será a principal referência intelectual para esse trabalho. Da obra de Weber, trabalharemos não com a interpretação de que existe uma relação entre a Reforma Protestante e o capitalismo moderno mas, com o que Giddens diz ser a novidade da sua interpretação "que as pessoas que dedicam a sua vida a atividades econômicas e à obtenção do lucro são ou indiferentes à religião, ou até hostis a ela, na medida em que suas aç̧ões visam exclusivamente o mundo 'material', enquanto a religião se interessa apenas pelo mundo 'não material'” (GIDDENS, 2005, p.182).
} 
fenômenos sociais em termos da ordem existente nas condições e nos níveis de sua manifestação, além de pôr em evidência as relações dinâmicas da ordem social ou de fatores sociais como as formas da vida. Do ponto de vista mais amplo, a sua tese da "previsibilidade no conhecimento científico da ação humana é tão possível, ou mais, do que no caso dos fenômenos naturais" (COHN, 2003, p. 119-120). Para Weber, compreender e ter experiência não são opostos nem irredutíveis entre si.

Quando Weber utilizou em sua obra Metodologia das Ciências Sociais uma análise sobre algumas das categorias da sociologia compreensiva, "não somente nos mostrou que a Sociologia se ocupa da existência de 'motivos pressupostos' da ação, de satisfações substituídas, de orientações impulsivas e coisas similares, mas também, em maior grau, considera que elementos qualitativos, totalmente 'incompreensíveis', de um processo de motivações o codetermina de modo mais estrito, também no que diz respeito à sua relação privada de sentido, em se tratando das consequências" (WEBER, 2001, p. 319).

\section{Ocupação recente dos cerrados brasileiros}

Os espaços de cerrados do Brasil estão situados na porção central do Brasil, sendo característica marcante no interior do Planalto Central do país. Engloba parte dos estados da Bahia, Goiás, Maranhão, Mato Grosso, Mato Grosso do Sul, Minas Gerais, Paraná, Piauí, São Paulo e Tocantins, além do Distrito Federal (figura 2). Sua ocupação teve início no século $\mathrm{XVI}$, se desenrolado por espasmos e em consequências de eventos desconexos. Foi um processo descontínuo, nucleado e especialmente desarticulado ${ }^{10}$. Até meados da década de 1960 , nos documentos e discursos oficiais, eram considerados como um dos grandes vazios nacionais e foram utilizados como áreas naturais de pastagem.

Trata-se de um território que vem passando por transformações significativas nas cinco últimas décadas, quando a atividade agropecuária praticada nos seus espaços de cerrados passou a ter um caráter mais comercial. Isso trouxe como consequência um importante processo de modernização e diversificação agrícola e o contingente de grandes estabelecimentos passou a ser uma das suas principais atrações para os agronegócios na

\footnotetext{
${ }^{10}$ Para uma reflexão no campo da historiografia sobre o processo de ocupação da parte ocidental do atual território brasileiro recomendamos os livros "Monções" e "Capítulos de Expansão Paulista", de Sérgio Buarque de Holanda, republicados pela Companhia das Letras (2014) e o livro "A Conquista do Oeste - A fronteira na obra de Sérgio Buarque de Holanda", de Robert Wegner, publicado pela Editora da UFMG (2000). Sérgio Buarque de Holanda é um dos principais interpretes do problema da formação da nacionalidade brasileira sem incorrer em um anacronismo.
} 
sua ocupação com a moderna agricultura e a pecuária extensiva. Uma outra situação que chama a atenção sobre esses espaços é que estão localizados em territórios de expansão de uma das últimas fronteiras agrícolas do país (a outra está na Região Norte).

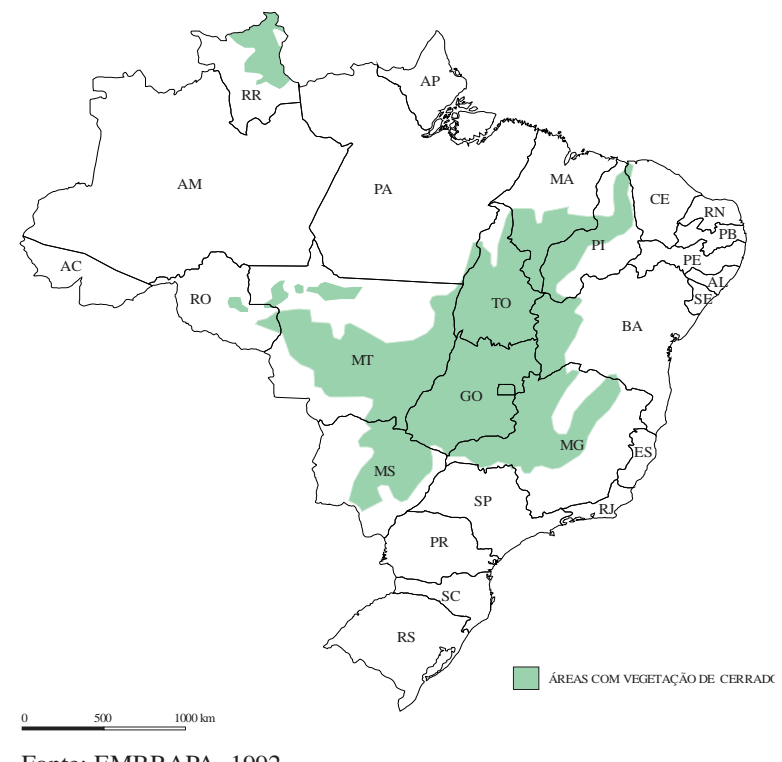

Figura 2 - Áreas com Vegetação Cerrados no Brasil

O lançamento de grandes projetos e programas ${ }^{11}$ governamentais, visando ocupar produtivamente a região Centro-Oeste do Brasil, especificamente os seus cerrados, transformou esse território em um ponto estratégico dentro do II Plano Nacional de Desenvolvimento do Governo Geisel (1974 - 1979) $)^{12}$. A modernização da agricultura seria um dos pontos importantes do II PND para viabilizar a ocupação dos cerrados brasileiro. 0 Estado desempenharia, a partir daquele momento, novos papéis, em um novo padrão de desenvolvimento agrícola, criando mecanismos de uma regulação estatal visando financiar, patrocinar e administrar a captura das margens de lucro na agricultura, no sentido de

\footnotetext{
${ }^{11}$ Foram inúmeros os programas especiais traçados a partir desse período para áreas com cerrados no território nacional, sendo os principais: Programa de Desenvolvimento do Centro-Oeste (PRODOESTE), Programa de Crédito Integrado $(\mathrm{PCl})$, Programa de Assentamento Dirigido do Alto Paranaíba (PADAP), Programa de Assentamento Dirigido do Distrito Federal (PAD-DF), Programa de Assentamento de Várzeas Irrigadas (PROVÁRZEAS), o Programa de Desenvolvimento dos Cerrados (POLOCENTRO), desenvolvido e executado pelo governo federal, influenciaram decisivamente a elaboração de novas metodologia que possibilitassem a ocupação de áreas do Cerrado e da elaboração e execução do Programa de Cooperação Nipo-Brasileira para o Desenvolvimento dos Cerrados (PRODECER).

${ }^{12}$ Dentre as metas contidas no II PND, a intensificação do processo de modernização da agricultura brasileira era uma das mais importantes. A partir dele, foram criados políticas e programas de desenvolvimento do Governo Federal, sozinho e/ou em parceria com instituições internacionais (governos/bancos, etc.) cujas ações, direta ou indiretamente tiveram algum reflexo na região Centro-Oeste e, em muitos casos, sobre áreas de cerrado do Brasil. "Não se trataram exclusivamente de programas setoriais; entretanto, introduzindo melhorias de infra-estrutura, tinham reflexo favorável sobre a produção agrícola" (CUNHA, 1994, p. 56).
} 
beneficiar os capitais integrados e garantir a sua autovalorização (GRAZIANO DA SILVA, 1996, p. 28).

A dinâmica que vem possibilitando a ocupação de novas áreas de cerrados no país com a agricultura moderna produtivista e intensiva de grãos, sobretudo de soja, e que permitiu um maior impulso ao desenvolvimento da agricultura da região Centro-Oeste do país foi acelerada a partir e no período da modernização conservadora ou modernização compulsória da agricultura brasileira ${ }^{13}$, aqui conceituada como um processo associado a profundas mudanças econômicas, com incremento da divisão do trabalho, com o uso de técnicas de gestão, tecnologia adaptada e o aumento dos serviços comerciais, que ocorreu entre 1967 e 1981. Quando o setor agrícola passou a adquirir importância central na expansão e diversificação das exportações do Brasil.

Um dos programas responsáveis por mudanças significativas nos espaços de cerrados da região Centro-Oeste, em parte dos espaços de cerrados dos territórios do Estado de Minas Gerais e Bahia, a partir do início da década de 1970, foi o Programa de Cooperação NipoBrasileira para o Desenvolvimento dos Cerrados - PRODECER ${ }^{14}$, concebido em 1974, objetivando promover a ocupação de extensas áreas dos cerrados, com uma metodologia de beneficiar, prioritariamente, setores ligados ao capital, propiciando a continuidade da expansão industrial (produção de maquinários modernos). Foram as facilidades prometidas

\footnotetext{
${ }^{13}$ No caso brasileiro, podemos afirmar que é consenso entre diversos autores, entre eles Guimarães, Muller, Kageyama e Graziano da Silva que o processo de modernização da agricultura se entende basicamente com as mudanças ocorridas na base técnica da produção agrícola que aconteceram no pós-guerra no Brasil (1945), a partir das importações de tratores e fertilizantes, num esforço de aumentar a produtividade no campo. Foram criadas as condições prévias para a formação do complexo agroindustrial ou, em outras palavras, para a transformação da agricultura numa atividade integrada pela indústria. Dinâmica que atravessou duas fases a partir dos meados da década de 1940: a primeira, com a criação de um mercado nacional para os insumos modernos e a segunda, com a instalação, após um período de suprimentos por meio de importações, das indústrias aptas a produzir aqueles insumos aqui mesmo, dentro do país. Para efeitos operacionais, neste texto, centraremos nossas análises a partir do final da década de 1960 e início da década de 1970, período da intervenção planejada na condução da atividade agrícola a um grau mais adiantado de sua marcha evolutiva, através da ruptura das principais barreiras erguidas contra o seu crescimento, quando "as forças agrárias modernas distinguem-se das tradicionais no modo de organizar a produção e a distribuição de suas atividades e na crescente urbanização de sua sociabilidade" (MULLER, 1988, p. 169).

${ }^{14}$ Nas negociações para viabilizar o projeto os bancos japoneses foram a fonte dos empréstimos, com a liderança de um dos seus organismos a JICA (Japan Internacional Cooperation Agency). O interesse japonês devia-se ao fato de serem totalmente dependentes de commodities agrícolas e à geografia do país, que não possibilita o desenvolvimento do setor agrícola de forma que ele seja capaz de suprir as necessidades do país. A experiência do PRODECER, que trouxe um grande ânimo a produção de grãos no Brasil, tornou-se inspiração para a criação em um país africano - Moçambique - de um Programa de cooperação triangular envolvendo Moçambique, Brasil e Japão para o desenvolvimento da agricultura das savanas tropicais - ProSAVANA. A implantação e financiamento desse Programa em Moçambique, assim como o PRODECER no Brasil, teve os seus estudos financiados pela Agência Japonesa de Cooperação Internacional - JICA. Em Moçambique, temos a existência de vasta área na sua Região Norte de predomínio do bioma Miombo, com características aparentemente similares aos do Cerrado do Oeste baiano.
} 
pelo Estado brasileiro, juntamente com os incentivos fiscais e creditícios presentes na sua proposta, que incentivaram a migração para essas áreas grandes empresas e agricultores experientes do Sudeste e Sul do país, a fim de que promovessem a instalação de grandes unidades agrícolas de caráter empresarial, com o uso de tecnologias modernas e intensivas em capital. O PRODECER deu considerável impulso à agricultura das regiões Noroeste do Estado de Minas Gerais e o Oeste da Bahia, bem como de partes com cerrados dos territórios dos Estados da região Centro-Oeste.

O PRODECER representou uma nova forma de intervenção estatal no direcionamento da fronteira agrícola. O Estado se imbui do papel de criar bases para que a acumulação capitalista no setor agrícola possa se reproduzir com ampla participação de outros setores organizados do sistema - o capital financeiro e o industrial, principalmente nas áreas de cerrado brasileiras. Esse processo ganha relevo porque a agricultura nessas áreas passa a desempenhar uma importante função econômica, "não tão importante por ser nova, mas por ser qualitativamente distinta" (OLIVEIRA, 1976, p. 15).

\section{A recente ocupação dos cerrados baianos a partir do PRODECER II e a recente ocupação dos cerrados piauienses}

O PRODECER ampliou a sua dimensão a partir de agosto de $1982^{15}$, evolução considerada "natural" pelos documentos dos organismos oficiais do período. Viabilizou-se em parte dos cerrados do território baiano, já que o projeto piloto implantado em cerrados do território do estado de Minas Gerais, desenvolvido no período de 1979 a 1982, para as estruturas governamentais, atingiu as metas programadas nos campos econômicos (ocupação com produção agrícola de um espaço que era considerado improdutivo economicamente) e sociais (constituição no campo de um segmento de produtores que incorporasse, sem questionamentos, uma nova forma de plantar determinada a partir de pacotes tecnológicos originários das agências e pesquisas com vínculos internacionais). As análises econômicas e políticas do período e os documentos oficiais limitaram-se sempre a comprovar a viabilidade da implantação da agricultura moderna, empresarial, de médio e grande porte para a produção de grãos nos cerrados em detrimento da agricultura tradicional praticada nesses espaços.

\footnotetext{
${ }^{15}$ Com base nos relatórios da JICA e da CAMPO.
} 
Com a consolidação do processo de ocupação dos cerrados baianos, por questões locacionais, e a partir das concepções presentes no PRODECER, foi possível a abertura de mais uma rota com destino à ocupação dos cerrados de Estados da região Nordeste do país, especificamente os cerrados do Piauí.

\subsection{A ocupação dos cerrados baianos: trajetória de um território}

Os cerrados baianos, localizados na sua Região Oeste (figura 3), situam-se em um território que, com a introdução e a implementação de uma moderna agricultura a partir do final da década de 1970, além de ter modificado completamente a sua paisagem, com a construção de um grande números de estradas que cortam todo os seus espaços, a constituição de novos aglomerados habitacionais e a pratica de uma agricultura irrigada em larga escala, foi, diante dos dados presentes nos organismos de planejamento do Estado da Bahia, um dos poucos fatos econômicos importantes ocorridos nos últimos 60 anos no Estado e um dos grandes responsáveis pela mudança do perfil econômico, político e geográfico da produção agrícola baiana. A estrutura agrária regional foi o grande "pano de fundo" sobre o qual se desenvolveu o processo de modernização capitalista nos cerrados baianos, onde áreas até então tidas pelas classes dominantes baianas como "vazias" e "marginais", quase que inacessíveis, tornaram-se uma nova realidade econômica, influenciadas por fatores externos.
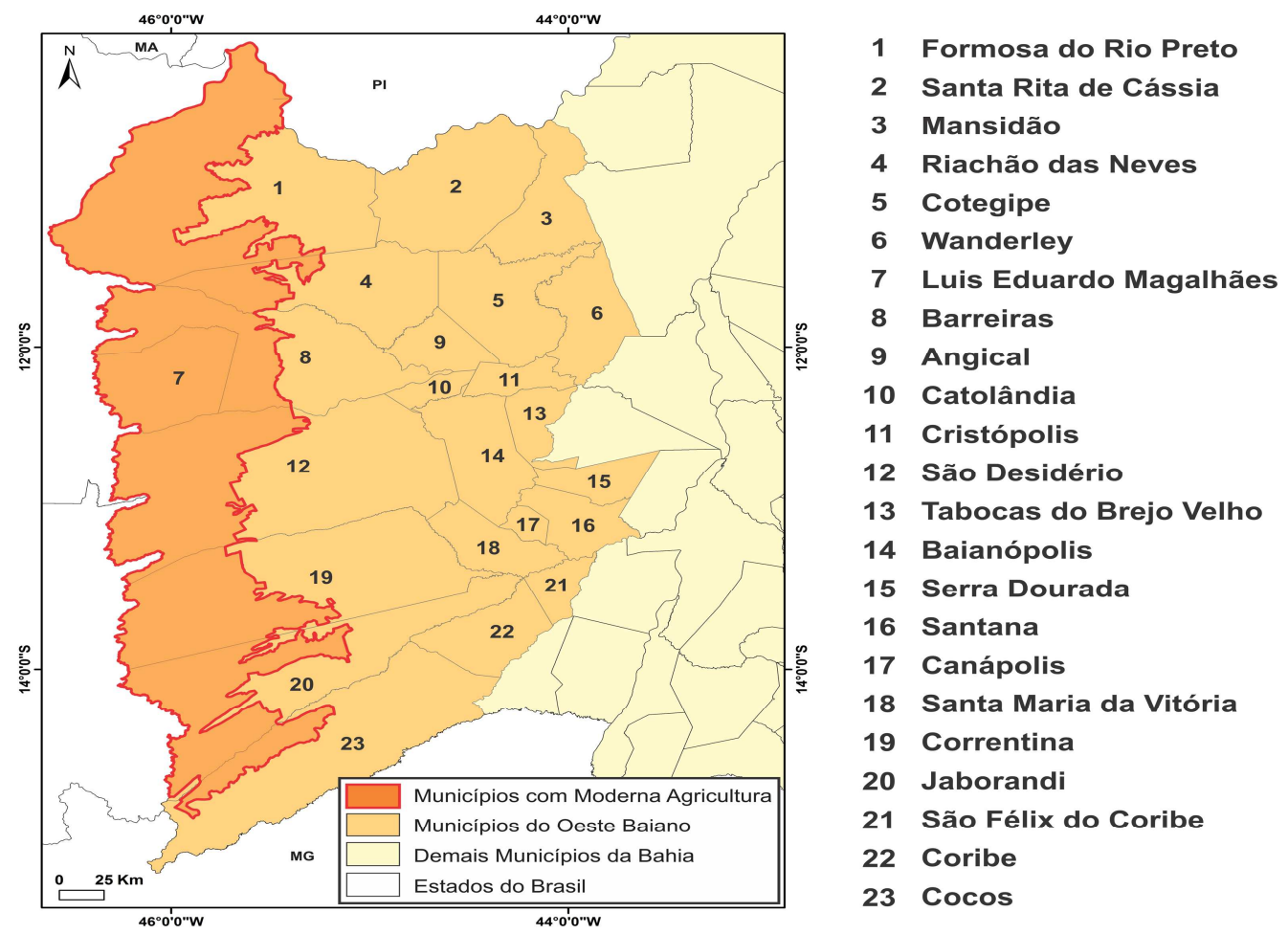

Figura 3 - Municípios da Região Oeste da Bahia, áreas de cerrados com moderna agricultura. Fonte: IBGE 
A introdução do processo de modernização agrícola nos espaços de cerrados do Oeste da Bahia foi comandada por uma estrutura com vínculos nacionais e com fortes relações internacionais, além de uma escala de decisões expressivamente maior que a praticada historicamente pelo setor agrícola do Oeste Baiano. Até a chegada da moderna agricultura nos cerrados baianos, a agricultura do Estado apresentava um quadro cambaleante, de pouco dinamismo e com dificuldades para completar a sua integração interna e externamente. A incorporação da economia agrícola do Estado às novas regras ditadas externamente em poucos ramos aconteceu de forma abrupta, transformando a sua produção de grãos na principal atividade econômica do setor agrícola do Estado nas quatro últimas décadas e deu um novo papel na economia do Estado ao Oeste da Bahia.

Com a chegada de grupos de produtores individuais e empresas com tradição agrícola diferenciada daquela praticada anteriormente, a inclusão da região do Oeste baiano na rota de expansão da fronteira agrícola do país, no final da década de 1970, levou o governo do Estado a repensar sua forma de atuação na Região. A introdução da moderna agricultura produtivista era algo irreversível, a possibilidade de inclusão das áreas de cerrados baianos na agenda de ocupações do cerrado nacional era uma realidade e, por isso, seria necessária a criação, por parte do Estado, de "mecanismos e instrumentos para apoiar os verdadeiros empresários" (BAHIA, 1980, p. 7).

A base produtiva territorial que ali se encontrava, no conjunto dos seus espaços regionais, que fazia a ocupação e o uso estável da terra em um número maior de produtores, foi desestruturada por não incorporar a produção agrícola moderna. As desigualdades econômicas e sociais aparecem de forma nítida, pois os bolsões de pobreza, antes camuflados pelos baixos níveis de produtividade da agropecuária regional, vistos então como circunstâncias conjunturais, agora se revelam devido ao forte contraste entre as propriedades e os espaços (urbanos e rurais) inclusos na moderna agricultura quando comparados com os espaços que estão fora. A pobreza convive ao lado das novas paisagens onde os grandes tapetes verdes, plantados com as culturas de soja, café e/ou "pintados" com pontas brancas de grandes contingentes de gados, irrigados pelos sistemas de pivôs centrais, foram transformados em símbolos da modernidade regional.

Os espaços de cerrados baianos, quando incorporados à nova dinâmica agrícola, passaram a ser o destino de fluxos migratórios originários tanto das áreas agrícolas regionalmente menos atingidas pelo avanço do moderno capitalismo, como de municípios da região Nordeste e das regiões Sul e do Sudeste do país, que passaram por um processo de modernização da base técnica agrícola na década de 1970. Os territórios dos municípios de Barreiras, Luís Eduardo Magalhães, São Desidério, Angical, Riachão das Neves, Formosa do 
Rio Preto e Correntina (principais produtores de grãos do Estado) foram transformados em uma das poucas áreas de grande interesse de reprodução do capital no Estado, rompeu resistências ao crescimento econômico do seu setor agrícola e passou a ser tratado como importante centro para o processo de acumulação dos setores avançados do capital nacional e internacional ${ }^{16}$.

\subsection{A recente ocupação dos cerrados do Piauí}

Quanto aos cerrados do Estado do Piauí (figura 4), tratam-se de espaços localizados em territórios que passaram muito recentemente ${ }^{17}$ a apresentar mudança substancial nas suas paisagens e a despontar como um dos importantes polos de modernização agropecuária da Região Nordeste. O processo de ocupação dos cerrados piauienses também teve início do século XVII por vastas fazendas de pecuária extensiva, em decorrência da migração de colonos oriundos de outras regiões (baianos, paulistas/bandeirantes e sesmeiros), incentivados pelo Poder Público Central.

A ocupação dos cerrados piauienses com a moderna agricultura de grãos é uma situação recente, especificamente nas suas partes sudoeste e sul. São esses espaços que vêm passando por profundas transformações rumo à incorporação da modernização agrícola com características conservadoras, onde a histórica tradição presente no setor agrícola do Estado, concentradora de terras, não sofre abalos. Até a chegada da produção de grãos, a partir dos meados da década de 1980, esses espaços vivenciaram um início de ocupação acelerada com a implantação de megaprojetos agropecuários (pecuária e cajucultura), incentivados por várias linhas de crédito de instituições públicas, principalmente através de programas e projetos traçados pela Superintendência do Desenvolvimento do Nordeste SUDENE e financiamentos públicos, principalmente através do Banco do Nordeste.

Segundo o bispo de Bom Jesus, Dom Ramón López Carrozas ${ }^{18}$, "o processo de chegada e renovação [populacional e econômica aos espaços de cerrados do Sul do Piauí], é de uns 8 anos".

"tudo diferente, era tudo praticamente estático por muitos anos foi assim. [...] todo esse tempo aqui era mais ou menos como uma terra estática, era aquela coisa, não tinha estrada para escoar a produção, a economia era algo parado, não tinha

\footnotetext{
${ }^{16}$ As suas transformações não eliminaram, no entanto, as suas estruturas pré-capitalistas. Ao contrário, preservaram. Tanto que, na Subdelegacia do Ministério do Trabalho, em Barreiras, existe um grande número de fotografias e documentos de autos impetrados pelos fiscais do Trabalho de Barreiras, com denúncias sobre a existência de relações trabalhistas próximas à escrava em toda a Região.

${ }^{17}$ Aproximadamente dez anos após à ocupação dos cerrados baianos.

${ }^{18}$ Entrevista com o Bispo de Bom Jesus do Piauí, que se encontra na região desde 1967, realizada no dia 21 de outubro de 2013.
} 
produtores, não tinham empresários, era um lugar onde exportar era muito difícil, eu tive aqui padres que plantaram cebolas e diziam assim: esse ano eu consegui 20 mil quilos de cebolas e não consigo vender, então não planto mais cebolas,

Mas, de uns 8 a 10 anos, no máximo, começou a vir gente de fora, e essa gente de fora, sim, começou a plantar nas serras e no cerrado, começou a plantar onde não tinha nada nem ninguém, o caso é que, nos últimos 8 anos, aqui plantou, multiplicou, enfim, tudo evoluiu muito, as estradas foram aparecendo [...]."

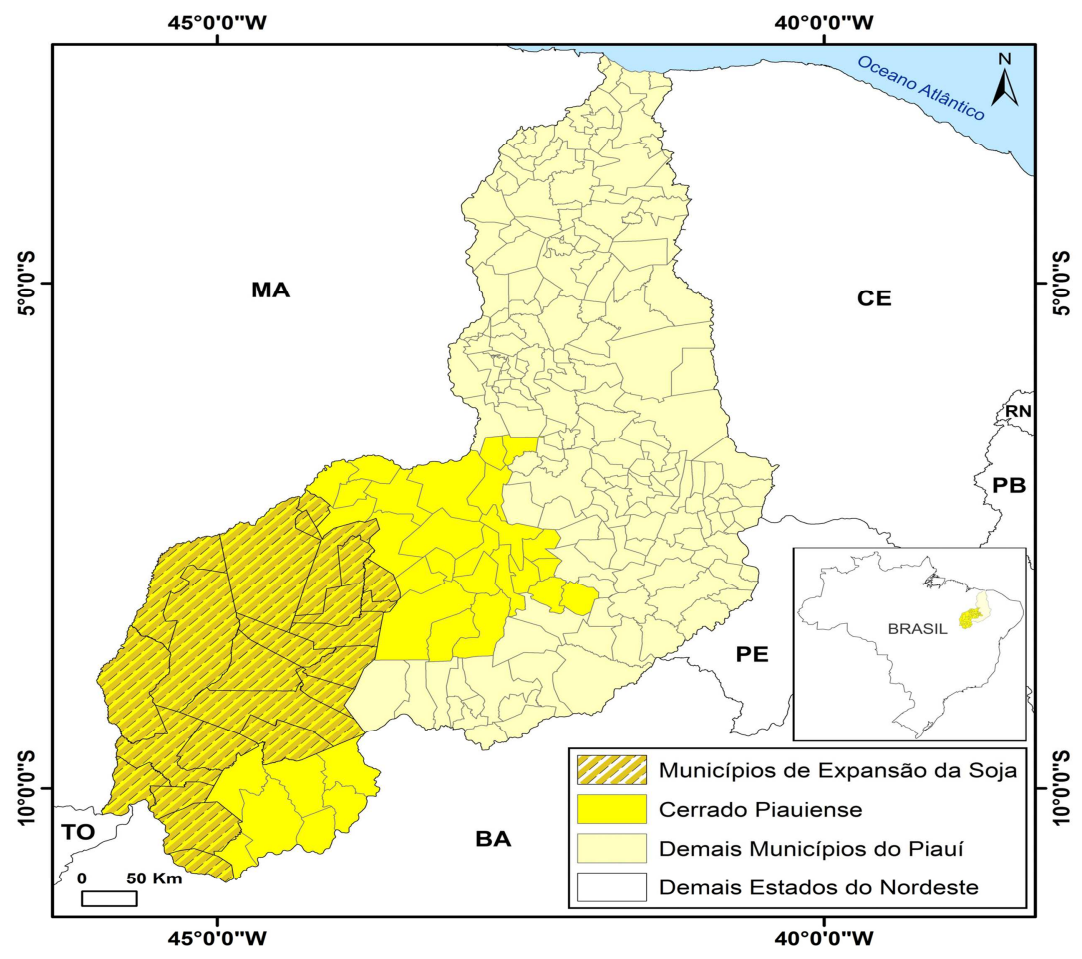

Fonte: Base Cartográfica IBGE 2010.

Figura 4 - Estado do Piauí, com destaque para sua área de cerrados.

Para Altair Fianco ${ }^{19}$, vice-presidente do Sindicato Rural de Uruçuí, grande produtor rural, com uma propriedade toda estruturada em produção de grãos e um dos representantes das comunidades externas que se deslocaram para o Sul do Piauí, foi uma ocupação que

"se deu da forma mais imprópria possível. Foi a partir dos grandes projetos da SUDENE, na época de 1970, onde se tiravam quantias enormes de dinheiro, e esse dinheiro nunca era aplicado na atividade-fim. Eles eram projetos grandes, geralmente, todos eles eram projetos de 20 mil hectares. Foram 26 projetos, onde sempre haviam políticos envolvidos, quando não, na totalidade, e o desvio dessa grande quantidade de dinheiro foi parar nas capitais do Nordeste. Isso fez que com o dinheiro tirado da atividade-fim, que era ou pecuária ou caju, mas não para o Piauí, se fosse um projeto de pecuária ia para o Pará, para o Maranhão, mas não para o Piauí, era muito seco, mas a atividade que eles tinham como meta mesmo era caju. Se produzisse todos esses hectares de caju, toda população do Piauí seria insuficiente para plantar e colher o caju, pois o caju é uma atividade de coleta

\footnotetext{
${ }^{19}$ Entrevista com o Senhor Altair Fianco, realizada no dia 22 de outubro de 2013.
} 
manual, logicamente que não foi feito para se produzir caju, mas para produzir riqueza para alguns pouco que viram nessa modalidade de ocupação a possibilidade de se fartar do dinheiro público, via SUDENE. Não era para dar certo, como não deu, mas, vamos dizer assim, que o grande primeiro passo, isso porque as terras se mostraram férteis, boas, talvez não para caju, mas para outras atividades; mesmo o caju, desde que fosse plantado para produzir. Isso foi na década de 1970 para 1980. Começou alguns projetos com arroz, também faraônicos, mas também inviáveis, financiando 11 mil hectares de arroz, numa fazenda sem uma colhedeira, quer dizer, voltado para pegar o dinheiro público e não produzir, mas sobrou os que realmente queriam produzir, e de 1985 para cá [...] vindo do Maranhão [...] em uma quantidade muito pequena, muito rudimentar."

Mesmo não sendo implementado em solos piauienses, aspectos metodológicos do PRODECER atuou como um primeiro passo importante, como elemento indutor do processo de ocupação e uso dos cerrados da Região Nordeste do Brasil. Foi a partir das suas primícias metodológicas que se tornou possível a "nova aventura" da ocupação dos cerrados piauienses com a moderna agricultura de grãos. A gênese do PRODECER, acompanhada das questões introduzidas a partir do Programa Corredor de Exportação Norte - $\mathrm{PCNE}^{20}$; (b) as condições apresentadas pelo Fundo Constitucional de Financiamento do Nordeste - FNE ${ }^{21}$, em que os novos empresários que se deslocavam para os cerrados piauienses obtiveram recursos para investimento de médio e longo prazo, com taxas de juros facilitadas, não superiores a $8 \%$ ao ano; (c) e mais os incentivos fiscais oferecidos pelo Estado do Piauí ${ }^{22}$, contribuíram em um processo de transformação gradual "sem violência"23, que, aos poucos,

\footnotetext{
${ }^{20}$ Após estudos da Companhia Vale do Rio Doce (CVRD), da Empresa Brasileira de Pesquisa Agropecuária (Embrapa), do BB, da Secretaria de Desenvolvimento Regional (que o coordenava), do BNB, do Banco da Amazônia, do Banco Nacional de Desenvolvimento Econômico e Social (BNDES), dos governos estaduais do Maranhão, Tocantins e Piauí e da Prefeitura Municipal de Balsas, foi lançado pelo Governo Federal, no ano de 1990, um Programa englobando um conjunto de projetos e medidas voltados para o desenvolvimento da região do cerrado setentrional brasileiro, que abrange o Oeste da Bahia, o Sul do Maranhão, o Sudoeste do Piauí e todo o Estado de Tocantins, através da ocupação produtiva e da viabilização do escoamento da produção tanto em nível interno, quanto em termos de exportação para o mercado europeu, com fretes substancialmente inferiores (MONTEIRO, 2002).

${ }^{21}$ Instituído em fins da década de 1980, importante mecanismo de incentivo à ocupação da terra e ao incremento da produção no Nordeste. O FNE consiste num dos fundos de desenvolvimento regionais criados a partir da Constituição de 1988. Prevê 1,8\% da arrecadação do IR e do Imposto sobre Produtos Industrializados (IPI), com a finalidade de financiar atividades produtivas na agropecuária, como também, na agroindústria, mineração e indústria, sendo que, metade de tais recursos deve se destinar à zona semiárida.

${ }^{22}$ Segundo Monteiro (2002), o Governo do Estado do Piauí, conforme Legislação dos Incentivos Fiscais (1996) que institui a Lei $\mathrm{N}^{\circ} 4.859$, de 27 de agosto de 1996, também ofereceu incentivos fiscais aos empresários industriais e agroindustriais que desejavam se instalar no Estado, sob a forma de dispensa do pagamento do Imposto sobre Circulação de Mercadoria e Serviço (ICMS). Para a autora, este foi um fato que pode explicar o significativo afluxo de produtores de várias regiões brasileiras que se deslocaram para os cerrados do Piauí com a intenção de investirem na produção de soja

${ }^{23} \mathrm{~A}$ opinião que o processo de ocupação dos cerrados do Piauí ocorreu sem violência é do Bispo de Bom Jesus Dom Ramón López Carrozas. Para setores dos Movimentos Sociais e da Universidade Federal do Piauí, essa visão do Bispo não é consenso no Estado, pois, resultado das denúncias sobre a violência agrária no Estado,
} 
vem culminando em uma ocupação com atividades agrícolas modernas, sob a direção principalmente de produtores com origem gaúcha, através da qual o espírito de aventura, que poderia exigir a agressividade ou mesmo a fraude, encaminha-se, paulatinamente, para uma ação mais disciplinadora e determinada na direção das condições geográficas gerais sobre as quais irá ocorrer a acumulação.

O que vem ocorrendo nos cerrados piauienses apresenta uma lógica que historicamente faz parte das relações estabelecidas entre as classes dominantes da Região Nordeste do Brasil e o Estado, desde a criação da SUDENE, em 1959, quando a entrada em ação dos mecanismos de dedução fiscal para os investimentos que poderiam ser realizados no Nordeste por empresas, grupos econômicos e empresários individuais permitiram levar a economia da Região a uma progressiva integração à dinâmica da economia nacional em que o processo de acumulação de capitais, a sua internacionalização produtiva e financeira, causou a anulação nacional da presença política de alguns setores sociais na Região e trouxe um resultado talvez não esperado que foi a desregionalização da economia regional (OLIVEIRA, p. 80, 1998).

A implementação da moderna agricultura de grãos, com os experimentos do cultivo da soja no Estado do Piauí teve o seu início em 1972, através da então Estação Experimental Apolônio Sales, do Ministério da Agricultura, com um programa de pesquisa com o apoio da Secretaria da Agricultura do Estado, da Sociedade Algodoeira do Nordeste Brasileiro S.A. Sanbra e também da participação da Associação Nordestina de Crédito e Assistência Rural do Piauí - Ancar/PI. Com a criação da Unidade de Execução de Pesquisa de Âmbito Estadual Uepae/Embrapa, em Teresina, esse programa teve continuidade no ano agrícola de 1977/78, contando com a cooperação do Centro Nacional de Pesquisa de Soja, hoje Embrapa-Soja (MONTEIRO, 2002). No entanto, parece consenso a compreensão de pesquisadores da Universidade Federal do Piauí e de produtores modernos, como Altair Fianco, de que o processo de ocupação produtiva do cerrado piauiense só foi realidade e se efetivou nos anos posteriores a $1990^{24}$, nos municípios de Uruçuí, Ribeiro Gonçalves e Baixa

existe na Assembleia Legislativa um Relatório Conclusivo da Comissão Parlamentar de Inquérito dos Conflitos Agrários e da Análise Jurídica das Alienações das Terras Públicas Patrimoniais, instalada em 1997, que teve como foco central discutir o processo de ocupações das terras nos cerrados piauienses. Nesse relatório recomenda-se, dentre uma série de outras medidas importantes: à própria Assembleia, a expedição de Decreto Legislativo anulando Títulos de Terras Definitivos, que foram formalizados sem o procedimento legal no Piauí e, especificamente, em municípios dos seus cerrados; ao Senhor Governador, que extinga órgãos públicos porque tiveram atuações que agravaram ainda mais o quadro fundiário conflituoso que o Estado apresenta.

${ }^{24} \mathrm{O}$ primeiro plantio da cultura da soja no Piauí foi registrado pelo IBGE em 1987, com 200 ha e repetido no ano seguinte (1988). Em 1989 a área plantada dobrou para 400 ha e por conta das condições da exploração do calcário na época esse crescimento foi paralisado nas safras 1990/91, 1991/92 e 1992/93. Somente a partir da 
Grande do Ribeiro, muito devido à qualidade das terras e a elevação do seu preço em Barreiras (Oeste da Bahia) e Balsas (Maranhão).

O processo e a intenção de ocupação dos cerrados do Piauí a partir do início dos anos de 1990 são semelhantes quando comparados aos interesses que motivaram o processo de ocupação dos cerrados da região Oeste da Bahia. Assim como na Bahia, a ocupação dos cerrados piauienses ocorreu a partir das experiências consolidadas nos cerrados mineiros, da recente ocupação dos cerrados baianos, e também a partir dos processos facilitadores do Estado, juntamente com os baixos preços das suas terras em relação às já ocupadas em espaços onde as fronteiras agrícolas estavam consolidadas, principalmente as do sul do país. As condições necessárias de correção dos solos com a aplicação de calcário, que poderia ser considerado problema, assim como ocorreu no início da ocupação dos cerrados do Oeste da Bahia, também não foram empecilhos. Pois, diferente do ocorrido com o Oeste da Bahia, o Sul do Piauí conta com a abundância de calcário, onde podem ser encontradas jazidas e reservas em grandes quantidades. Essa situação contribuiu preponderantes para a consolidação de grandes áreas produtoras de grãos nos cerrados piauienses. O papel da EMBRAPA, de outros organismos do Governo Federal, acompanhado do PCNE, os incentivos fiscais oferecidos pelo Estado do Piauí, juntamente com as condições apresentadas pelo FNE e de instituições privadas vinculadas à agricultura moderna e ao agronegócio, com experiências acumuladas em outras áreas de cerrados, exerceram papel preponderante na aceleração da ocupação das áreas de cerrados do Piauí.

Os novos agrupamentos econômicos, sociais e as estruturas que estão nos cerrados do Piauí contam com os receituários agronômicos e químicos prontos para a sua aplicação. Aspectos programáticos dos projetos e programas delineados anteriormente, visando à ocupação dos cerrados da região Centro-Oeste do país, de Minas Gerais e da Bahia, foram incorporados nos novos espaços produtivos e potencializaram o processo de modernização da agricultura dessa nova fronteira com maior velocidade no tempo. As estruturas públicas federais e estaduais criaram infraestrutura de transportes, energia, armazenagem e estimularam o desenvolvimento tecnológico, além de viabilizarem a exploração econômica de áreas cujas terras, a princípio, apresentassem problemas de produtividade. Ao setor privado, incentivos foram repassados pelos Estados e União. Para Telma Manganelli ${ }^{25}$,

safra agrícola de 1993/94, com o início da produção de calcário se iniciou um novo processo produtivo de grãos nos cerrados piauienses com o cultivo de soja, arroz, milho e algodão.

\footnotetext{
${ }^{25}$ Telma Manganelli é uma das representantes das primeiras famílias de gaúchos que chegou ao Oeste da Bahia, em 1986, e se deslocou definitivamente para os cerrados piauienses em 1999, para desenvolver suas atividades agrícolas no município de Bom Jesus.
} 


\begin{abstract}
"o que ocorreu nos cerrados do Piauí foi possível graças a toda a experiência acumulada na ocupação dos cerrados por parte dos primeiros grupos sociais que ali chegaram: acredito que na primeira fase no Oeste da Bahia a coisa foi um pouco mais difícil porque 'veio-se' do Rio Grande do Sul com pouca estrutura e também a área lá não era muito terrificada, não tinha muita tecnologia, foi um ano de início de descobertas lá. Também não tinha infraestrutura e isso a gente enfrenta até hoje, 'né'? Mas o processo todo foi um pouco mais complicado. Quando se veio embora para o Piauí, a gente chegou aqui e também não encontrou muita infraestrutura. Hoje já tem algumas mudanças bem significativas, mas no começo, quando a gente veio pra cá já com uma tecnologia bem mais avançada, já se trouxe, da Bahia para cá, uma tecnologia que se utiliza aqui. As terras aqui são muito produtivas. Acho que aqui o alavancar foi diferente, digamos, menos sofrido que no Oeste da Bahia."
\end{abstract}

O Estado do Piauí possui uma área de $250.934 \mathrm{~km}^{2}$, ocupando $16,20 \%$ da região Nordeste e 2,95\% do território nacional. De acordo com a Fundação Centro de Pesquisas Econômicas e Sociais do Piauí - Fundação CEPRO (1992), o Cerrado piauiense é o quarto mais importante do Brasil, ocupando uma área de 11.856 .866 milhões de hectares, o que corresponde a $46 \%$ da área do Estado, equivalendo a 5,9\% do Cerrado brasileiro e 36,9\% do nordestino. Do total, $70 \%$ correspondem à área de domínio e os 30\% restantes compreendem a vegetação de transição entre a Caatinga e o Cerrado, estendendo-se por vários pontos, de norte a sul do Estado, sendo sua maior concentração localizada na região Sudoeste e Extremo Sul. Estima-se que cerca de $10 \%$ desse ecossistema esteja sendo ocupado e utilizado com projetos agropecuários.

Assim como aconteceu com os cerrados baianos localizados na Região Oeste do Estado, devido a circunstâncias exteriores e ao evidente desenvolvimento das forças capitalistas no agro brasileiro, os cerrados do Piauí transformaram-se, nos últimos 20 anos, em mais um espaço agrícola do país que materializou modificações radicais nas suas paisagens, nos processos de trabalho, nos hábitos de consumo e na sua configuração geográfica, sendo considerada uma das últimas fronteiras agrícolas do Brasil a ser ocupada. Foram transformados em um grande produtor de commodities agrícolas, destacadamente de grãos, e que vem se ampliando também para outras ramificações da cadeia produtiva do setor agroindustrial.

O processo de ocupação de parte desses espaços com uma agricultura capitalista, além de ter provocado mudanças substanciais na estrutura produtiva, implicou a incorporação ao setor agrícola de novos grupos sociais com origem externas aos seus territórios e ao Estado do Piauí. Estes grupos construíram novas identidades, novas interações e novas formas de organização que, se por um lado trazem importantes ganhos econômicos para o Estado, de outro vêm acentuando as já profundas desigualdades econômicas e sociais entre os espaços 
locais e entre os grupos sociais dos seus territórios, com novos contornos espaciais, econômicos e demográficos. Tendo à frente os grandes proprietários de terras e empresas agrícolas, essa ação vem resultando em um rápido processo de modificações da sua estrutura demográfica, com uma crescente urbanização, notadamente nos centros urbanos dos municípios de Bom Jesus e Uruçuí e transformações da base técnica produtiva dos espaços rurais dos municípios de Alvorada do Gurguéia, Baixa Grande do Ribeiro, Bom Jesus, Brejo do Piauí, Corrente, Gilbués, Ribeiro Gonçalves, Santa Filomena e Uruçuí, todos localizados no Sul do Piauí.

O impulso modernizador dos cerrados do Piauí vem adquirindo relevância no volume de instalação de empresas. Isso se deu em virtude dos mecanismos de incentivos econômicos e fiscais, que se fortaleceram com as perspectivas de construções de obras nas áreas de logística e infraestrutura, principalmente dos corredores viários e portos destinados ao escoamento da produção dos cerrados piauienses, especialmente ao complexo portuário de Itaqui/Ponta da Madeira, em São Luís, no Maranhão, que tem intensa relação econômica com o mercado consumidor dos Estados Unidos e Europa, além se encontrar nas proximidades das granjas instaladas nos Estados do Nordeste.

Os cerrados piauienses contam ainda com uma infraestrutura em construção e/ou já nas suas etapas finais de uma ferrovia federal - a Transnordestina (que passa, literalmente, por dentro de territórios de municípios que compõem o cerrado piauiense), a BR-230, que permite o escoamento da produção por meio de uma infraestrutura intermodal e será complementada internamente com a construção de uma rodovia através do Governo do Estado, denominada de Transcerrado, que corta $300 \mathrm{~km}$ de cerrados situados entre as serras, onde estão instaladas as grandes empresas e modernos agricultores, e estradas pavimentadas (PI-140 e 141 e BR-135) que atravessam o Polo produtor de grãos de norte a sul.

Para a Fundação CEPRO, o cerrado piauiense apresenta também várias vantagens competitivas, como o seu potencial hídrico (são banhados pelos rios Parnaíba, Gurguéia, Paraim, Uruçuí-Preto e Uruçuí-Vermelho); o clima e o solo contribuem na produção de grãos, tanto de sequeiro como irrigado, além de ocorrer um bom índice pluviométrico que pode superar $1.000 \mathrm{~mm}$ ao ano.

Para um grupo de técnicos funcionários de Estado, produtores e representantes da sociedade civil que tivemos conversas e realizamos entrevistas, algumas sem autorização de gravações, foi comum a percepção de uma mistura de entusiasmo e preocupação com o futuro dos municípios situados nos espaços de cerrados do Piauí: (1) o entusiasmo, diante da possibilidade de que a nova dinâmica econômica, com a produção de grão que se 
instalara, modificasse e reduzisse o quadro de desigualdade social que assola todo o Estado do Piauí; (2) preocupação, porque as transferências de volumosos recursos estaduais para a grande produção e grupos econômicos vindos de fora do Estado não eram novidade no Piauí. Nessas conversas, sempre se referiam a um processo anterior, em que foram transferidas grandes quantidades de recursos financeiros pelos bancos oficiais para plantio de caju nos espaços de cerrados, e os projetos foram implantados em números reduzidos e inviabilizados por conta de gestões consideradas irresponsáveis pelos entrevistados; (3) duas outras preocupações, referentes aos conflitos ambientais e fundiários, que a população não percebia possibilidades nem interesse de resolução das estruturas de poder, diante do atual quadro de funcionamento e desaparelhamento do aparato estatal do Piauí.

A característica concentradora do uso e da posse da terra, presente na história do Piauí, assim como da Bahia, contribuiu efetivamente para a consolidação do modelo de ocupação agrícola nos espaços dos seus cerrados. A moderna agricultura de grãos produtivista, com novos padrões tecnológicos, utilizou-se fartamente da desorganização da escrituração imobiliária, da elevada disponibilidade de terras e, consequentemente, dos seus preços baixos nos cerrados baianos e também do Piauí. Esse quadro fundiário foi um dos elementos básicos para o processo de aceleração de mudança da base técnica da agricultura regional e serviu como sustentáculo para expansão e consolidação do novo modelo agrícola nacional nos espaços regionais.

Os cerrados piauienses apresentam aspectos bastante peculiares, principalmente físicos e geográficos, o que torna difícil a sua comparação com outros espaços econômicos de cerrados, como o da Bahia, por exemplo. Porém, há grandes similitudes políticas. Trata-se de um território cujos municípios detêm grandes extensões e estão muito distantes dos centros decisórios políticos e econômicos dos seus Estados. Antes da chegada da moderna agricultura as relações políticas dos municípios que fazem parte dos cerrados do Piauí com a capital do Estado, assim como ocorria entre os municípios do Oeste da Bahia, resumiam-se aos processos eleitorais e às trocas de pequenos favores entre as suas lideranças políticas e - Governo Central. Tais relações e reivindicações não contemplavam ou não eram prioritárias as reivindicações de caráter estrutural. As pautas de reivindicações limitavam-se a buscar soluções para problemas pessoais ou para aqueles que diretamente diziam respeito à apropriação de aparelhos do Estado que funcionam na Região. 
O processo de modernização agrícola, que ocorre nas serras e cerrados do Sul e Sudoeste do Piauí, não desestruturou a base produtiva ${ }^{26}$ que se encontra presente no conjunto dos espaços territoriais dos municípios que tiveram os seus cerrados incorporados com a produção de grãos, principalmente soja, pelo fato que esses espaços que passaram a ser ocupados não contavam com atividades produtivas significativas e economicamente determinante ao Estado.

O acesso à tecnologia, a créditos e a insumos, como resultado do processo de modernização conservadora, vem beneficiando, essencialmente, a agricultura de exportação, acentuando o tratamento diferenciado entre os agrupamentos sociais que fazem parte do campo. Entre os municípios visitados, os que mais nos chamaram atenção foram Bom Jesus e Uruçuí. Destacam-se com importantes alterações em sua dinâmica agrícola e urbana nos últimos cinco anos. Para os organismos de Estado, esses dois municípios, por terem se transformado nos maiores produtores agrícolas piauienses, devido à produção moderna de grãos, sobretudo de soja, transformaram-se, em curto espaço de tempo, em uma das poucas áreas de grande interesse de reprodução do capital no Estado, ao tempo em que criou perspectivas de crescimento e desenvolvimento econômico, porém sem a natureza patrimonial das sus relações políticas. Os dos municípios desempenham um papel de enorme significação para a consolidação da agricultura moderna no Estado, porque, mesmo de forma localizada, romperam resistências ao crescimento econômico do seu setor agrícola e transformam radicalmente as suas paisagens urbanas e rurais. Nos últimos anos receberam um volume considerável, para os padrões locais, de migrantes, predominantemente sulistas, e de empresas dos mais variados ramos do setor agrícola. Com a instalação desses grupos, as mudanças, tanto na dinamização da infraestrutura do espaço urbano quanto nos costumes até então estranhos aos piauienses, são radicais. Ocorreram instalações de empresas ligadas diretamente à produção, mas também de comércio e serviços destinados à demanda dos novos moradores, permitindo, da mesma maneira, que a população local tivesse acesso a determinados serviços pouco frequentes no seu cotidiano: churrascarias, padarias, pizzarias etc., com a incorporação de novos hábitos.

\footnotetext{
${ }^{26} \mathrm{~A}$ implantação da moderna agricultura aconteceu, primordialmente, nos espaços de serras, e a pequena produção e/ou a agricultura familiar no Piauí está instalada nos vales e beiras de rios, com uma territorialidade ampla e definida.
} 


\section{Conclusão: síntese dos dois processos - fundamentais semelhanças e dessemelhanças}

A gênese da dinâmica do crescimento econômico dos cerrados dos Estados da Bahia e do Piauí está nos seus setores agrários, que experimentam significativa expansão da produção, tanto do ponto de vista do volume físico quanto da produção de grãos, tendo a soja, o milho e o algodão cultivados nos seus cerrados como culturas principais do processo de crescimento das suas economias agrícolas. No caso da soja, o seu cultivo era praticamente inexistente no Estado da Bahia antes de 1980 e também nos cerrados do Piauí até os meados da década de 1990. Datam de 1981 os registros do IBGE sobre a primeira colheita realizada nos cerrados baianos, que, já na primeira década da sua introdução (1980 - 1990), apresentou uma taxa de crescimento anual da área plantada superior a $68 \%$ a.a.. Para os cerrados do Piauí, o primeiro plantio da cultura da soja foi registrado pelo IBGE em 1987, com 200 ha, e repetido no ano seguinte, 1988. Em 1989, a área plantada dobrou para 400 ha e somente a partir da safra agrícola de 1993/94 que se iniciou um novo processo produtivo de grãos nos cerrados piauienses com o cultivo de soja, arroz, milho e algodão.

$\mathrm{O}$ incremento das suas áreas plantadas e da produção nos espaços dos cerrados baianos e nos cerrados do Piauí foi resultado dos vários incentivos governamentais, entre eles creditícios, pesquisas, apoio técnico e uma forte demanda do mercado externo, principalmente de farelo de soja. Segundo boletins e informativos da Secretaria da Agricultura do Estado da Bahia, a soja produzida no Estado é toda cultivada em municípios dos territórios Oeste e Bacia do Rio Corrente. A concentração espacial da moderna agricultura no Oeste da Bahia vem se formando cada vez de forma mais direta em manchas distintas, que transformam esses espaços em sinônimo de riqueza nos discursos produzidos pelos organismos oficiais dos Governos Estaduais e Municipais.

A produção de grãos, especificamente soja e milho, está fortemente concentrada em Estados localizados nas regiões Sul e Centro-Oeste do país. Nos últimos anos, vêm sendo observadas expansões expressivas em espaços e territórios historicamente menos representativos no agronegócio brasileiro. O processo de expansão e deslocamento é gradativo e passou a ocorrer de forma ordenada e planejada para espaços das regiões Norte e Nordeste a partir do PRODECER, acompanhado do PCNE, dos incentivos fiscais oferecidos pelos Estados do Nordeste e mais as condições apresentadas pelo FNE, em que os "novos" empresários que se deslocavam para a Região poderiam ter acesso a recursos para investimento de médio e longo prazo, com taxas de juros facilitadas, não superiores a $8 \%$ ao 
ano. Fruto desse deslocamento, segundo o Banco do Nordeste do Brasil ${ }^{27}$, as áreas de produção de grãos do Nordeste, especificamente soja, cresceram entre 1990/91 e 2008/09, respectivamente, $469,0 \%$ e $637,5 \%$.

No Nordeste, a produção de soja está concentrada em três estados: segundo a CONAB, Bahia, Maranhão e Piauí responderam na safra de 2008/09, respectivamente, por 58,1\%, $23,4 \%$ e $18,5 \%$ da produção regional. Tanto na Bahia como no Piauí, a sua produção se encontra concentrada em apenas $30,4 \%$ dos municípios das regiões nas quais se instalou a moderna agricultura. Essa concentração da produção da soja, nos espaços de cerrado deste estudo, considerando os municípios maiores produtores, segundo percentual da participação na produção da Região Nordeste, pode ser verificada a seguir (quadro 1).

\begin{tabular}{|l|c|c|}
\hline Município & Estado & Participação (NE) \\
\hline São Desidério $^{28}$ & Bahia & $17,8 \%$ \\
\hline Barreiras & Bahia & $8,1 \%$ \\
\hline Luís Eduardo Magalhães & Bahia & $7,1 \%$ \\
\hline Correntina & Bahia & $6,9 \%$ \\
\hline Formosa do Rio Preto & Bahia & $4,8 \%$ \\
\hline Riachão das Neves & Bahia & $3,2 \%$ \\
\hline Uruçuí & Piauí & $8,8 \%$ \\
\hline
\end{tabular}

Quadro 1 - Municípios da Bahia e do Piauí, segundo participação na produção de soja no Nordeste Safra 2006/07. | Fonte: Avaliação do FNE e elaborado a partir de dados do IBGE, 2012.

Essa concentração da produção é, portanto, uma característica comum aos dois espaços de cerrados ocupados com a moderna produção agrícola nos territórios dos dois Estados. Consequentemente, os benefícios do processo desse desenvolvimento também são concentrados, restritos em determinados espaços dos municípios produtivos, o que reduz seu impacto no âmbito territorial. A produção de grãos, especificamente soja, mesmo se considerando uma atividade econômica importante, está limitada a um baixo número de municípios com cerrados no território dos dois Estados. Nesses municípios, a produção de grãos desempenha papel importante e fundamental para as suas economias. No caso dos municípios dos cerrados piauienses, durante as entrevistas, percebemos que a sua diversificação era mínima; enquanto no caso dos municípios do Oeste da Bahia, que incorporaram a moderna agricultura nos cerrados, existe uma agropecuária comercial mais diversificada, além de outras culturas importantes como o milho, o algodão e o café.

\footnotetext{
${ }^{27}$ Avaliação do FNE Rural, 2012.

${ }^{28}$ O município de São Desidério, no último levantamento realizado pelo IBGE em 2012, foi apontado como o que tem o maior PIB agrícola do País.
} 
Não há possibilidade de tratarmos o processo de modernização conservadora, ora ocorrendo em diversos espaços do agro brasileiro, de forma homogênea. Reconhecemos que os princípios econômicos que nortearam o processo de modernização conservadora na agricultura brasileira são únicos, porém, em relação ao papel das estruturas sociais que se formaram no caso do Oeste baiano e que vêm se constituindo no Sul e Sudoeste do Piauí, estabelecem um processo diferenciado no território nacional, dadas as características e singularidades do processo da formação histórica dos dois espaços. Nos dois casos, não foram incorporados espaços e grupos sociais significativos do seu território, que resistiram a outros valores culturais e persistiram com suas relações e atividades econômicas e sociais marginais do ponto de vista produtivo.

A desarticulação do espaço regional reflete-se nas esferas políticas, em virtude da ausência de processos considerados modernos e do desenvolvimento de estruturas altamente diferenciadas, no que diz respeito às instituições e aos seus papéis políticos específicos. As estruturas políticas estão presas à centralização do sistema com orientações e objetivos específicos e pontuais. Apesar do enfraquecimento das antigas elites, suas práticas e formas de atuação são adotadas pelas novas lideranças políticas que se formam. Essas novas lideranças políticas construídas nos espaços da moderna agricultura e formadas por pessoas (agricultores e empresários) que vieram de outros contextos sociais não têm demonstrado sensibilidade e compromisso com as exigências das novas formas de organização econômica e com os problemas sociais decorrentes. O processo de ocupação dos cerrados do Oeste da Bahia e dos cerrados do Sul do Piauí não se caracterizou, pelo espírito aventureiro, não contém originalidade e nem a racionalidade para uma ação disciplinadora, quando estudados a partir das qualidades adequadas à moral capitalista, como o cálculo e a previdência, que são, na concepção weberiana, situações definidoras no processo de viabilização de uma dinâmica possível de formar uma mentalidade compatível com o moderno capitalismo. O que aconteceu nos espaços de cerrados do Oeste da Bahia e do Sul do Piauí foi diferente da "aventura" que ocorreu no processo de ocupação do Oeste norte-americano. $O$ processo de modernização agrícola que se desenvolveu e vem se desenvolvendo nesses espaços tratou-se, principalmente nos seus inícios, de transformações com violência e sem civilidade - grilagens de terras e contratações de trabalhadores para desenvolver atividades em condições análogas ao trabalho escravo -, sem cordialidade - onde as ondas de propostas de separatismo territorial, muito em voga atualmente nos dois espaços, levam em consideração somente a vontade e os interesses dos novos agricultores - e não representa nenhum tipo de aventura e/ou risco aos modernos produtores do agronegócio brasileiro, já que parte significativa dos empréstimos financeiros contraídos junto a instituições públicas, durante o processo inicial de ocupação dos dois cerrados, não foi paga e parte dessas dívidas se encontra securitizada. Além disso, o tamanho da sua produção hoje é determinado pelas empresas processadoras que têm as suas sedes nos países de mando do capitalismo internacional. 


\section{Referências}

BAHIA. Governo do Estado (1980). Ocupação Econômica do Oeste: programa básico. Salvador: Governo do Estado da Bahia.

BANCO DO NORDESTE (2012). Avaliação do FNE Rural. Série Avaliação de Políticas e Programas do BNB. Fortaleza: BNB.

BENDIX, Reinhard (1986). Max Weber: um perfil intelectual. Brasília: UNB.

BRASIL. Ministério da Fazenda (1979). Banco Central do Brasil. Acordo de empréstimo externo celebrado entre Agência de Cooperação Internacional do Japão e Banco Central do Brasil. Brasília, DF: MF / BCB.

BRASIL. Ministério da Agricultura (1982). Coordenadoria de Assuntos Econômicos. Avaliação do Programa de Cooperação Nipo-Brasileira para Desenvolvimento dos Cerrados (Prodecer). Brasília, DF: MA.

COHN, Gabriel (2003). Crítica e Resignação. São Paulo: Martins Fontes, 2003.

CORRÊA, Roberto Lobato (1995). Espaço: Um conceito-chave da Geografia. In: CASTRO, Iná Elias de, GOMES, Paulo César da Costa, CORRÊA, Roberto Lobato (Org.). Geografia: Conceitos e Temas. Rio de Janeiro: Bertrand.

CUNHA, Aércio S. (Coord.) (1994). Uma avaliação da sustentabilidade da agricultura nos cerrados. Brasília: Ipea. 254p.

GALINDO, Osmil, SANTOS, V. Monteiro dos. Centro-Oeste: Evolução recente da economia regional (1995). IN: Federalismo no Brasil - desigualdades regionais e desenvolvimento: São Paulo: FUNDAP: EDUSP. p. 157 - 194.

GIDDENS, Anthony. Capitalismo e moderna teoria social. Lisboa: Editorial Presença, 2005.

GRAZIANO DA SILVA, José (1996). A nova dinâmica da agricultura brasileira. Campinas, SP: Editora da Unicamp.

HABERMAS, Jürgen (2000). O discurso filosófico da modernidade. São Paulo: Martins Fontes.

HAESBAERT, Rogério. "Gaúchos" e baianos no "novo" Nordeste: entre a globalização econômica e a reinvenção das identidades territoriais (1996). In: CASTRO, Iná Elias de; GOMES, Paulo César da Costa; CORRÊA, Roberto Lobato (Org.). Questões atuais de reorganização do território. Rio de Janeiro: Bertrand. p. 367-415.

HAESBAERT, Rogério.. Des-territorialização e identidade: a rede "gaúcha" no Nordeste. (1997). Niterói: Editora da Universidade Federal Fluminense.

HOLANDA, Sérgio Buarque de. (2014). Monções. São Paulo: Companhia das Letras.

HOLANDA, Sérgio Buarque de. (2014). Capítulos de Expansão Paulista. São Paulo: Companhia das Letras.

JOLY, Aylton Brandão. (1970). Conheça a vegetação brasileira (1970). São Paulo: Edusp; Polígono.

KAGEYAMA, Ângela. Novo padrão agrícola brasileiro: Do complexo rural aos complexos agroindustriais (1990). In: DELGADO, Guilherme et al (Org.). Agricultura e políticas públicas brasileira: Brasília: Ipea. (relatório n. 127).

MINAYO, Maria Cecília de Souza (1992). O Desafio do conhecimento. São Paulo-Rio de Janeiro: HUCITECABRASCO.

MONTEIRO, Maria do Socorro Lira. Ocupação do cerrado piauiense: estratégia empresarial e especulação fundiária (2002). 250 f. Tese (Doutorado em Economia) - Instituto de Economia, Universidade Estadual de Campinas, Campinas, SP.

OLIVEIRA, Francisco de. A economia Brasileira: Crítica à razão dualista (1976). Seleção CEBRAP 1; Questionando a Economia brasileira. 2. ed. São Paulo: Brasiliense/Edições CEBRAP. 
OLIVEIRA, Francisco de. A metamorfose da arribaçã: fundo público e regulação autoritária na expansão econômica do Nordeste (1990). Novos Estudos Cebrap, São Paulo, n. 27, p. 67-92, jul.

OLIVEIRA, Nelson. O capitalismo no Oeste da Bahia (1983). Cadernos do Ceas. Salvador, n. 86, p. 22-36. jul./ago.

PIAUÍ. Assembleia Legislativa do Estado do Piauí (1998). Relatório Conclusivo da Comissão Parlamentar de Inquérito dos Conflitos Agrários e da Análise Jurídica das Alienações das Terras Públicas Patrimoniais. Teresina: Alepi.

PIAUÍ. Secretaria de Planejamento (2012). Fundação Centro de Pesquisas Econômicas e Sociais do Piauí Fundação Cepro. Piauí em Números - 8. Teresina.

SAN MARTIN, Paulo; PELEGRINI, Bernardo (1984). Cerrados - uma ocupação japonesa no campo. Rio de Janeiro: Codreci.

SANO, Edson Eyji, SANTOS, Clóvis Caribé Menezes dos, SILVA, Euzebio Medrado da, CHAVES, Joselisa Maria (2011). Fronteira Agrícola do Oeste Baiano: Considerações sobre os aspectos temporais e ambientais. Revista Geociências, Volume 30, N.3. São Paulo: p. 479 - 489.

SANTOS, Clóvis Caribé Menezes dos (2011). Oeste Baiano: ocupação econômica, formação social e modernização agrícola. In: FAGUNDES, Erivaldo (Org.). Sertões da Bahia: formação social, desenvolvimento econômico, evolução política e diversidade cultural. Salvador, Arcádia.

SANTOS, Clóvis Caribé Menezes dos; VALE, Raquel (Orgs.) (2012). Oeste da Bahia: trilhando novos e velhos caminhos do Além São Francisco. Feira de Santana: Editora da Uefs.

SANTOS Filho, Milton (Coord.) (1989). O processo de urbanização no oeste baiano. Recife: Sudene. (Série de Estudos Urbanos, 1).

SANTOS Filho, Milton; FERNANDES, Ana; ALMEIDA, Paulo Henrique (1988). A modernização do campo nos cerrados baianos. Espaço \& Debates, São Paulo, v. 8, n. 25, p. 63-75.

SANTOS, Milton (1978). Por uma geografia nova. São Paulo: HUCITEC.

SANTOS, Milton; SILVEIRA, M. Laura (2001). O Brasil: território e sociedade no início do século XXI. São Paulo: Record.

SCHLUCHTER, Wolfgang (2011). Paradoxos da modernidade: cultura e conduta na teoria de Max Weber. São Paulo: Editora Unesp.

SENEDA, Marcos César. (2008). Max Weber e o problema da evidência e da validade nas ciências empíricas da ação. Campinas, S.P.: Editora da UNICAMP.

SOLINÍS, Gérman (2009). O que é o território ante o espaço? In: RIBEIRO, M. T. F., MILANI, C. R. S. (Org.). Compreendendo a complexidade socioespacial contemporânea. Salvador: EDUFBA.

SOUZA, Jessé de. A atualidade de Max Weber no Brasil. Revista CULT, São Paulo, n.124, mai. 2008. Disponível em: < http://revistacult.uol.com.br/home/blogs/compre/?p=270>

SZMRECSÁNYI, Tamás (1983). Análise de economia agrícola. Cadernos de IFCH UNICAMP, Campinas, v. 7, julho.

WALLERSTEIN, Immanuel (2000). A reestruturação capitalista e o sistema-mundo. IN: Globalização excludente: Desigualdade, exclusão e democracia na nova ordem mundial. Petrópolis: Vozes, 2000.

WEBER, Max. (2004). A ética protestante e o espírito do capitalismo. São Paulo: Companhia das Letras.

WEBER, Max (2001). Metodologia das Ciências Sociais. Campinas, SP: Editora da UNICAMP, V. 1 e 2.

WEGNER, Robert (1999). Os EUA e a fronteira na obra de Sérgio Buarque de Holanda. In: SOUZA, Jessé (Org.). O malandro e o protestante. Brasília: Editora da UnB.

WEGNER, Robert (2000). A conquista do Oeste - a fronteira na obra de Sérgio Buarque de Holanda. Belo Horizonte: Editora da UFMG. 